\title{
収縮型PVCゲルアクチュエータの構造と駆動特性
}

\author{
山野 美咲* 小川尚 希* 橋本稔* \\ 高 崎緑* 平 井 利 博*
}

\section{Structure and Characteristics of a Contraction Type PVC Gel Actuator}

\author{
Misaki Yamano*, Naoki Ogawa*, Minoru Hashimoto*, \\ Midori Takasaki* and Toshihiro Hirai*
}

\begin{abstract}
A poly vinyl chloride (PVC) gel actuator shows great potential for use as an artificial muscle because of such positive characteristics as movement in the air, large deformation, and being light in weight. A bending type actuator using PVC gel was studied previously [3]. In order to construct an artificial muscle it is necessary to compose an actuator which has the characteristics of contraction type deformation. In this study we propose an electrode arrangement for the PVC gel actuator. Also, we investigate the characteristics of the proposed actuator experimentally and show the effectiveness of the actuator as an artificial muscle. The proposed actuator has a layered structure using mesh type electrodes. The experimental results showed that the contraction rate of the actuator was about $13 \%$, the response rate was $7[\mathrm{~Hz}]$, and the output force was about $3[\mathrm{kPa}]$. The characteristics of the PVC gel actuator are shown to be very effective for constructing an artificial muscle.
\end{abstract}

Key Words: Actuator, Artificial Muscle, PVC-gel, Mesh Electrode, Layered Structure

\section{1.は じめに}

高分子材料は軽量・柔軟で加工性に優れることから, 人工筋 肉の候補として注目され, 活発な研究が行われている。しかし, これらは溶液中でのみ駆動可能であるものや, 屈曲変形のみ可 能であるものが多く, 筋肉のように収縮させようとすると変位 量が少ないなど課題が残されている.

人工筋肉としての条件は, 人間の筋肉の特性と近似している, もしくはこれを上回る特性を有していることが望ましいと考え られる. 人間の筋肉は収縮率約 $30 \%$, 発生応力 $0.3[\mathrm{MPa}]$, 応答 性 $10[\mathrm{~Hz}]$ といわれている [1]. 高分子材料を用いた収縮型アク チュエータの例として導電性高分子 [2] と誘電性エラストマ [2] が挙げられる，前者は収縮率と発生応力に優れるが応答性が低 く, 後者は発生応力と応答性に優れるが収縮率が小さいなど一 長一短があり, 生体筋のような特性を有する高分子アクチュエー 夕はいまだ研究開発の途上にある.

一方, 平井らによって研究されている PVCゲルアクチュエー 夕 [3] は収縮率と応答性がよいという特徵を持つ. また, 一般に ゲルは溶媒の継続的な供給が必要だが, 可塑剤を含む PVC ゲ ルはその必要がないため空気中での動作が可能で，電場を駆動

原稿受付 2008 年 12 月 19 日

*信州大学

* Shinshu University

口本論文は有用性で評価されました。
要因とすることから比較的制御しやすいという特徵がある。こ のような利点を持つことから, PVC ゲルを用いた屈曲変形, レ ンズ型変形に関する研究 [3]〜 [5] が行われてきた. しかし人工筋 肉を構成するためには，収縮変形を実現することが必要である． そこで，本論文では PVC ゲルの収縮駆動により人工筋肉を創 製することを目指し，その構造と駆動特性を明らかにする。単 層構造での駆動特性に加え，より大きい変位を得るために積層 構造のアクチュエータを作製し，その駆動特性について調べた.

本論文の構成は次のとおりである. 次の章において PVCゲ ルの作製方法, 弾性率, 屈曲変形メカニズムを説明する。 3 章 において収縮型 PVCゲルアクチュエータの構造を提案し, 4 章 で単層構造の基本的な駆動特性を明らかにし，5章では積層構 造の駆動特性を示す． 6 章で実験結果に対する考察を行い，7 章 において本論文をまとめる。

\section{PVC ゲルアクチュエータ}

\subsection{PVC ゲルの作製}

これまで, PVCゲルはポリ塩化ビニル, 可塑剤としてフタル 酸ジブチル $(\mathrm{DBP})$, 溶媒としてテトラヒドロフラン $(\mathrm{THF})$ を用いてきた 6$]$. しかし, 可塑剤として DBP を用いると, 正 極に対する粘着力が大きく電圧除去時の応答性が低いという問 題があった。 そのため, 本研究では可塑剤としてより粘着性の 低いアジピン酸ジブチル（DBA）を用いた．PVCゲルの作製 法は次のとおりである.PVCに DBA を加えて THF に溶解す 
る.PVCが完全に溶解したら, 溶液をテフロンシャーレにキャ ストし, 水平な場所におき数日間放置する。 THF が完全に蒸発 したらゲルを取り出し適当な大きさに切り出して使用する。ア クチュエータの組成としては PVC と DBA の重量比を 10:40 から 10:110の間で調整する.

\subsection{PVC ゲルの弾性率}

PVC ゲルの弾性率はアクチュエー夕の特性を決める基礎特性で あることから, 引張り試験により弾性率を測定した。試料の組成は $\mathrm{PVC}: \mathrm{DBA}=10: 90$ (DBA90）と 10:110（DBA110）のものを 用いた. 長さ $30[\mathrm{~mm}]$, 幅 $10[\mathrm{~mm}]$, 膜厚 $1,000 \sim 1,600[\mu \mathrm{m}]$ の 試料を用い, 引張り速度 $20[\mathrm{~mm} / \mathrm{min}]$, チャック間距離 $20[\mathrm{~mm}]$ の試験条件で引張り試験を行った. DBA90 と DBA110の試料 についてそれぞれ 7 回の引張り試験を行い, 弾性率の最大のも のと最小のものを除いて平均弾性率を求めた。弾性率は PVC に可塑剤が 9 倍入っている DBA90 が 7.3 [kPa], 可塑剂が 11 倍入っている DBA110 で $3.4[\mathrm{kPa}]$ であった. 可塑剤の添加に より弾性率の低下が見られた。

\subsection{PVC ゲルの屈曲変形のメカニズム}

屈曲型 PVC ゲルアクチュエータを用いて PVC ゲルの屈曲 変形のメカニズムについて説明する. 屈曲型 PVC ゲルアクチュ エータの概観とモデル図をそれぞれ Fig. 1 と Fig. 2 に示す. Fig. 1 より電場を与えることにより $90[\mathrm{deg}]$ 以上の屈曲変形を 生成されることが分かる。 このアクチュエータは板状の PVCゲ ルが両側から電極に挟まれている。電荷が電極の負極からゲル に注入されると正極に移動し, 放電により消失する. 正極で放 電する前に電荷は正極付近に蓄積され，ゲルの正極表面への静 電気的付着を促進する。これにより, 正極付近でゲルのクリー プ変形がおこり，ゲルは折れ曲がる（Fig. 2)，ゲルで誘発され た変形は単純な屈曲ではなく, 屈曲はクリープ変形によって誘 発され正電極の先端に集中する. 電場を除去するとゲルの正極
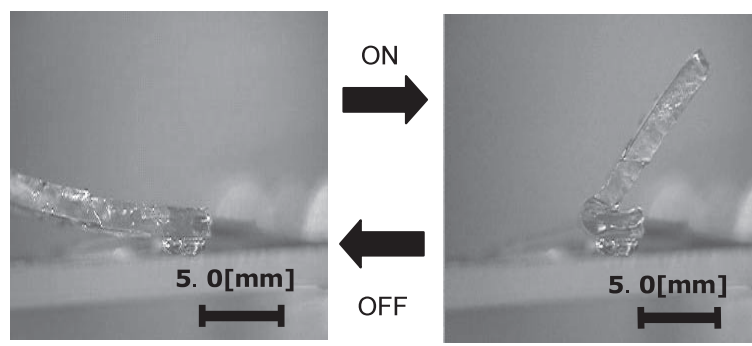

Fig. 1 Overview of a bending action

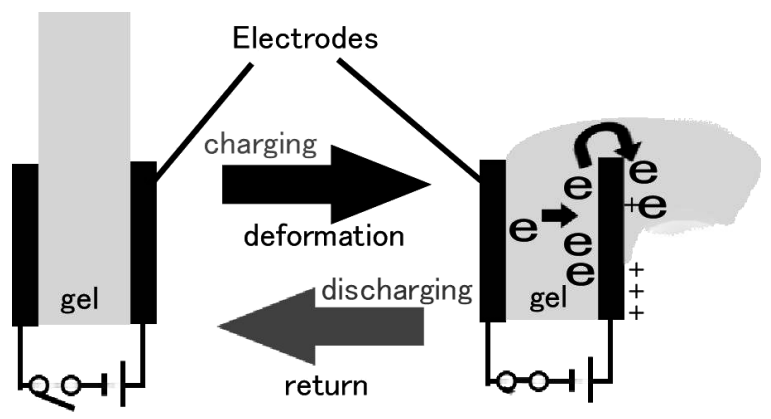

Fig. 2 Bending mechanism of PVC
への粘着性は放電により消失し, ゲルは本来備わっている弾性 により元の形状に戻る。また電場の増加によりゲルの変形量は 増大する [3].

\section{3. 収縮型アクチュエータの構造}

2 章で述べた PVC ゲルの屈曲変形のメカニズムを考慮して 収縮駆動を可能とするアクチユエー夕構成法を提案する。最初 に基礎実験としてメッシュ状電極を正極とした PVC ゲルを作 製した. PVCゲルは電圧を印加すると, 正極上に這い出して変 形する特性を持つことから，正極としてメッシュ状の電極を用 いた. ガラス板の上にアルミニウムテープを負極として貼り付 けPVCゲルをのせ，正極にステンレスメッシュをかぶせた試 料を作製した。

この試料に, 超高抵抗 / 微小電流計 $(\mathrm{R} 8340 \mathrm{~A}$, ADVANTEST）を用い， 1,000 [V] の電圧を印加した. 観察は光学顕 微鏡（オリンパス（株）, BX50）と CCD デジタルカメラ（オ リンパス (株)，DP70）を使用したＦig. 3 はこの試料に電場 を印加する前 (a), 電場を印加したとき (b) の様子を真上から 観察したものである. クリープ変形によりメッシュ状の正極に 向かって PVC ゲルが這い出してきている様子が分かる. これ により, 両電極間の距離が減少し, 厚さが薄くなる.

この特性を利用した収縮型アクチュエータの構造を Fig. 4 に 示す。メッシュ状正極の両側をゲルで挟むことにより，電圧印 加時にゲルがメッシュの隙間に引き寄せられて全体として収縮 する。電圧を除去するとゲルの弾性により元の形状に戻る。こ の基本構造を積層させることにより, 変位量を増大させ収縮型 アクチュエータとして動作させる.
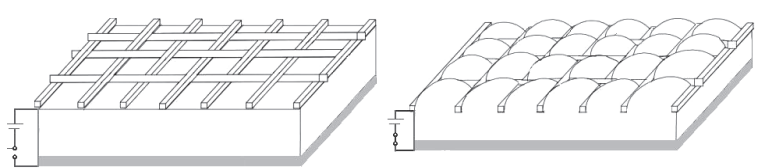

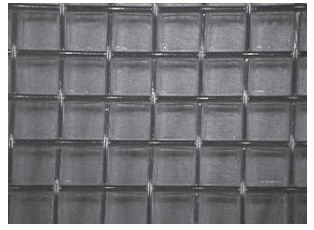

(a)

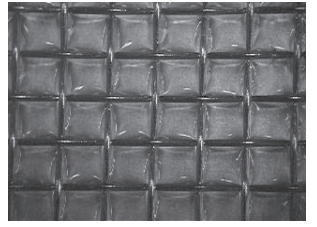

(b)
Fig. 3 Response to electric field (a) discharge (b) charge
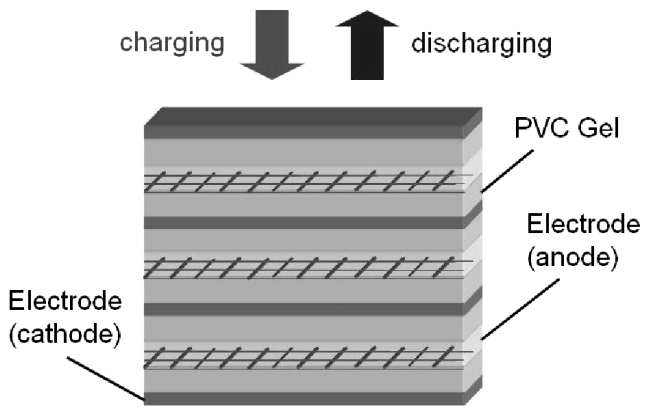

Fig. 4 Schematic drawing of the PVC gel actuator 


\section{4. 単層構造の駆動特性}

提案した収縮型 PVC ゲルアクチュエータの基本的な駆動特 性を明らかにするために，基本単位構造の試料を作製し，駆動 実験を行った. Fig. 5 に実験に用いたアクチュエータ試料の構 造を示した。負極にステンレス箔（厚さ $0.008[\mathrm{~mm}]$ ), 正極に ステンレスメッシュの電極を用い, PVCゲルは縦 $10[\mathrm{~mm}]$, 横 $10[\mathrm{~mm}]$, 膜厚 $0.6 \sim 0.9[\mathrm{~mm}]$ を用いた. ガラス板の上にステン レスメッシュを固定し, PVCゲルを重ねてその上にステンレス 䇴をのせた，正極のステンレスメッシュはガラス板に固定しや すいように $20[\mathrm{~mm}] \times 30[\mathrm{~mm}]$ の大きさにした

\section{1 変位特性}

駆動特性の評価のために, 正極のメッシュサイズや印加電場に より, アクチュエータの厚さ方向の変位量がどのように変化する かを調べた，変位計測にはレーザー式変位計測器（KEYENCE， LK-G30）を用いた。

試料として DBA110 を用い, 印加電場 600 [V/mm] で, メッ シュサイズが 20 の場合の計測結果を Fig. 6 に示す.メッシュ サイズは 1 インチ当たりのワイヤの本数で表されている。 した がって,メッシュサイズの小さなものほど粗いメッシュとなる. 電場印加により $0.15[\mathrm{~mm}]$ の変位量が得られていることが分か る.また, 同じ条件でメッシュサイズのみを変えて変位量を測 定した．実験に用いたメッシュのメッシュサイズとメッシュ内の 隙間の体積, 変位量の関係を Fig. 7 に示す.メッシュサイズが 小さくなるにつれて変位量は増加している. メッシュサイズの 小さいものほど陌間の体積は大きいことから変位量はメッシュ の隙間の体積に依存すると考えられる.

次にDBA90 と DBA110を用い, 印加電場を 270〜 $1,800[\mathrm{~V} / \mathrm{mm}]$ の範囲で 4 段階に調整して実験を行った．正極の メッシュサイズは 20 （厚さ $0.4[\mathrm{~mm}]$ ）である.このときの印加

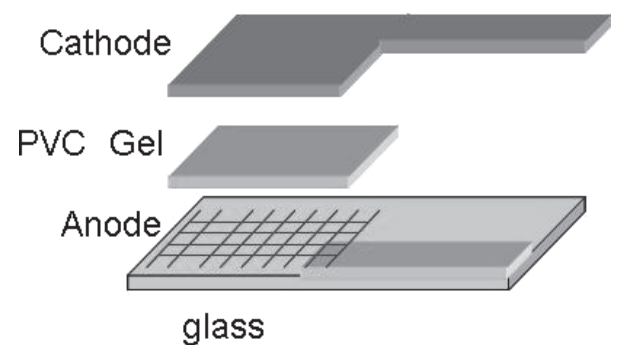

Fig. 5 Schematic drawing of a single layer model

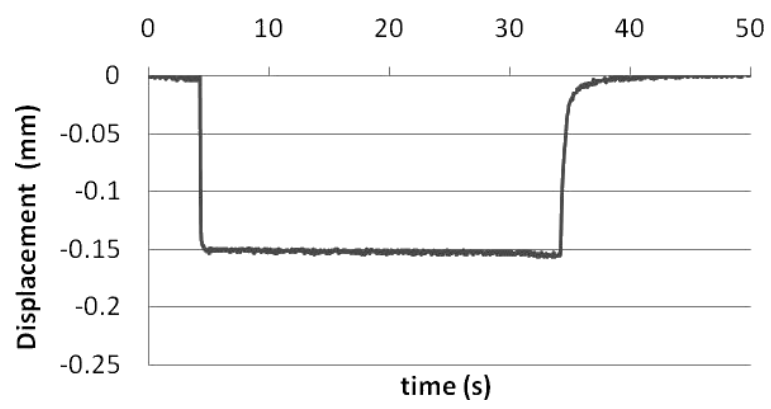

Fig. 6 Displacement (DBA110, $20[\mathrm{mesh}], 600[\mathrm{~V} / \mathrm{mm}])$
電場と変位量との関係を Fig. 8 に示す。電場の増加に伴い変位 量は増していることが分かる. DBA110の場合, $1,100[\mathrm{~V} / \mathrm{mm}]$ 印加時に $0.18[\mathrm{~mm}]$ の変位が発生した. これはアクチュエータ 全体の厚さの約 $13 \%$ にあたる，また，DBA90 とDBA1 10 の変 位量を比較してみると, DBA110 のほうが変位量がわずかに大 きく, 可塑剤である DBA の増加により変位量が増していること が分かる。また $1,700[\mathrm{~V} / \mathrm{mm}]$ までは放電や短絡なく変位した.

Fig. 9 にDBA100に1,100 [V/mm] 印加時の電流の変化を 超高抵抗/微小電流計（R8340A, ADVANTEST）を用いて計 測した結果を示した，正極のメッシュサイズは 20 である。電流 值は電場の増加とともに大きくなるが, $1,100[\mathrm{~V} / \mathrm{mm}]$ の印加 時で最高 $30[\mu \mathrm{A}]$ 程度になっており, かなり効率がよいことが 分かる. 電力はこのとき $0.03[\mathrm{~W}]$ となった.

\section{2 発生応力}

単層構造の PVC ゲルアクチュエータの発生応力を測定した. 電場印加時に PVC ゲルと負極の間に引力が発生しないため, 外 部からの引張り力により $\mathrm{PVC}$ ゲルと負極は剥離する。これを防

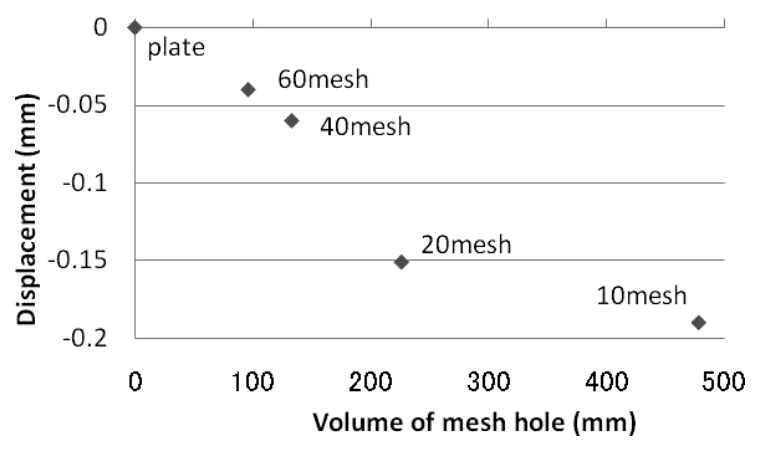

Fig. 7 Relationship between displacement and volume of mesh hole (DBA110)

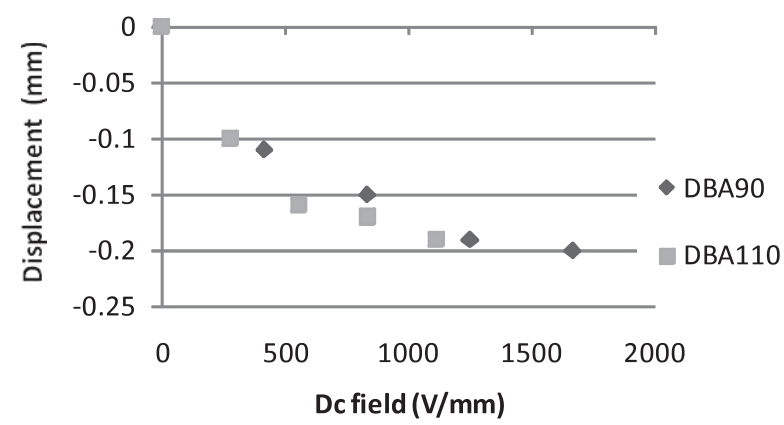

Fig. 8 Relationship between displacement and dc field (DBA90, DBA110)



Fig. 9 Current (DBA110, $20[\mathrm{mesh}], 1,100[\mathrm{~V} / \mathrm{mm}])$ 
ぐため, 負極を PVCゲルで覆った. さらに, 負極のステンレス 板（厚さ $0.2[\mathrm{~mm}]$ ）上に樹脂棒を接着し, 軸継手を用いてロー ドセル T-1 (NEC 三栄社製) と継いだ，正極にステンレスメッ シュ（メッシュサイズ 20）を用いた．試料の大きさは縦 10 [mm], 横 $10[\mathrm{~mm}]$, 膜厚 $0.6[\mathrm{~mm}]$ である. 印加電場が $1,250[\mathrm{~V} / \mathrm{mm}]$ のときの DBA90 の発生応力を Fig. 10 に示す. 約 $1.0[\mathrm{kPa}]$ の 発生応力が得られていることが分かる. また, 印加する電場に よる発生応力の変化を DBA90 と DBA110 について測定した.

Fig. 11 にその結果を示した。電圧が大きいほど発生応力が増 加している. 印加電場 1,660 [V/mm] の場合, DBA90 で最大約 $1.3[\mathrm{kPa}]$, DBA110 で $1.1[\mathrm{kPa}]$ の発生応力が確認できた. 可 塑剂である DBA の減少により, 発生応力が増加することが分 かった。

\section{3 応答性}

本アクチュエータの応答性を明らかにするために周波数応答 の実験を行った。アクチュエータに加える電圧を $500[\mathrm{~V}]$ とし て電源の ON-OFF を繰り返した. ON-OFF の周波数を $0.1 〜$ $10[\mathrm{~Hz}]$ の間で変化させ, そのときの変位の振幅を測定した.

DBA90 と DBA110 の変位のゲイン線困を Fig. 12 に示した.

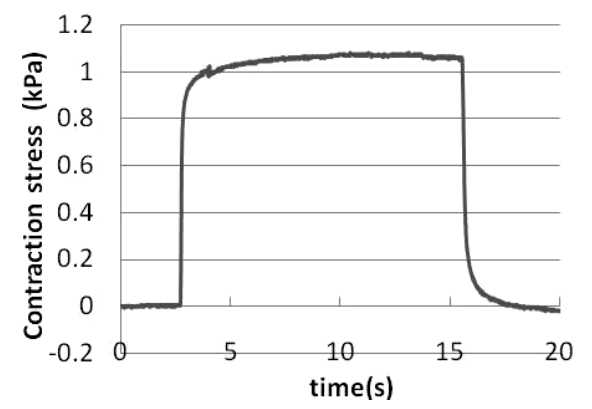

Fig. 10 Output contraction stress (DBA110, 1,250 [V/mm], $20[$ mesh])

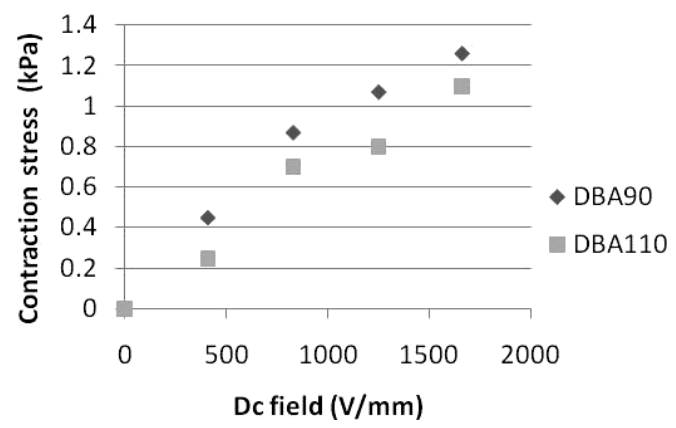

Fig. 11 Relationship between contraction stress and dc field

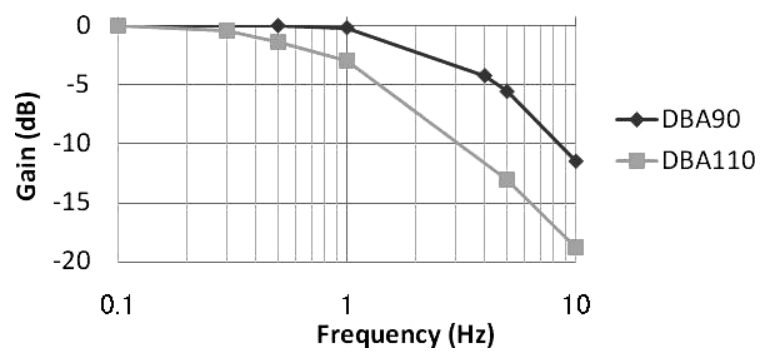

Fig. 12 Gain diagram in displacement (DBA90, DBA110)
$-3[\mathrm{~dB}]$ になるまでのバンド幅は, DBA90 で $3[\mathrm{~Hz}], \mathrm{DBA} 110$ で $1[\mathrm{~Hz}]$ となっていることが分かる. DBA110に比べDBA90 のほうがやや良好な応答性がみられた。 これは可塑剤の含有量 が少ないほど弾性率が上がることに起因していると思われる。

\section{5. 積層構造の駆動特性}

変位量を増大させるために, 提案した基本構造を 10 層積層し たアクチュエータを作製し，その駆動特性を調べた。 また，可 塑剂である DBA の量を DBA40，DBA60，DBA80 と単層構 造に比べ減少させて，応答性の向上を試みた。

Fig. 13 に多層 PVC ゲルアクチュエータの構造を示した. 各 電極と両側の電極端子をステンレスワイヤで結線して多層構造 アクチュエータを作製した。作製したアクチュエータの概観を Fig. 14 に示した. ゲル試料 $(20[\mathrm{~mm}]$ 角, 膜厚約 $0.4[\mathrm{~mm}], 10$ 枚）と, 負極（ステンレス箔, 厚さ $0.008[\mathrm{~mm}]$ ), 正極（ステ ンレス網状電極, メッシュサイズ 20 , ワイヤ径 0.19 [mm], 厚 さ $0.4[\mathrm{~mm}]$ ) をそれぞれ 5 枚用いて, 全高 $8.5[\mathrm{~mm}]$ のアクチュ エータを作製した。

\section{1 変位特性}

Fig. 15 に変位量と電場の強さの関係を示す. DBA40の場合, $1,200[\mathrm{~V} / \mathrm{mm}]$ の電場を与えたとき, 最大変位は約 $1.0[\mathrm{~mm}]$ であ り，アクチュエータ全高の約 $12 \%$ の収縮率になる.ゲルの組成は 異なるもののほほ同条件（正極 $20[\mathrm{mesh}]$, 電場 $1,100[\mathrm{~V} / \mathrm{mm}]$ ) の単層構造の実験結果では収縮率が $13 \%$ 程度, 変位量が約 $0.18[\mathrm{~mm}]$ であった。このことから単層と多層で収縮率は同程 度で, 変位量は基本構造を重ねた分増加していることが分かる。 また, 単層構造の結果と同様に, DBAの増加により, 収縮率が わずかに増大する傾向にあることが分かった.

\section{2 発生応力}

発生応力と印加電場の関係を Fig. 16 に示す. DBA40 の場

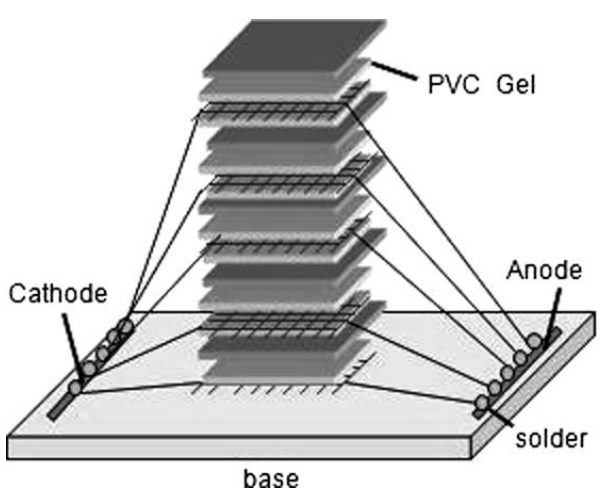

Fig. 13 Schematic drawing of the layered PVC gel actuator

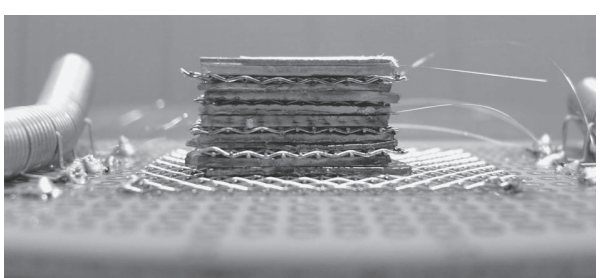

Fig. 14 Picture of a ten-layer PVC gel actuator 


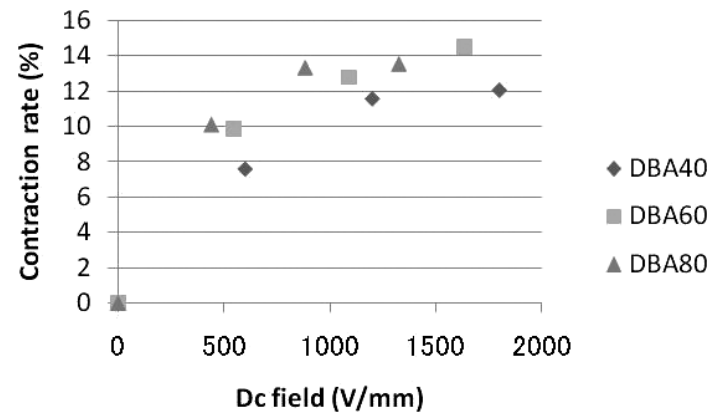

Fig. 15 Relationship between contraction rate and dc field

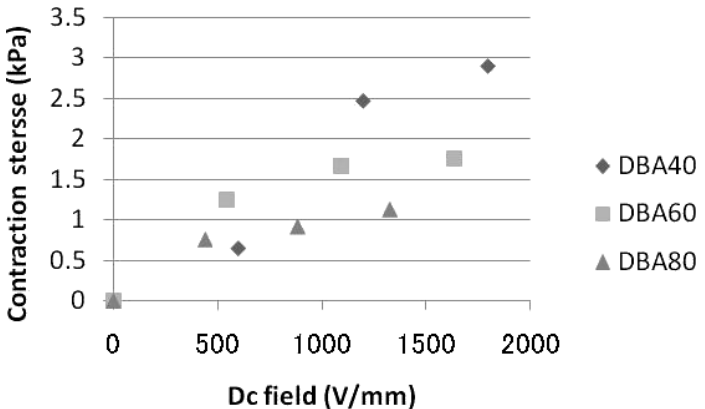

Fig. 16 Relationship between contraction stress and dc field

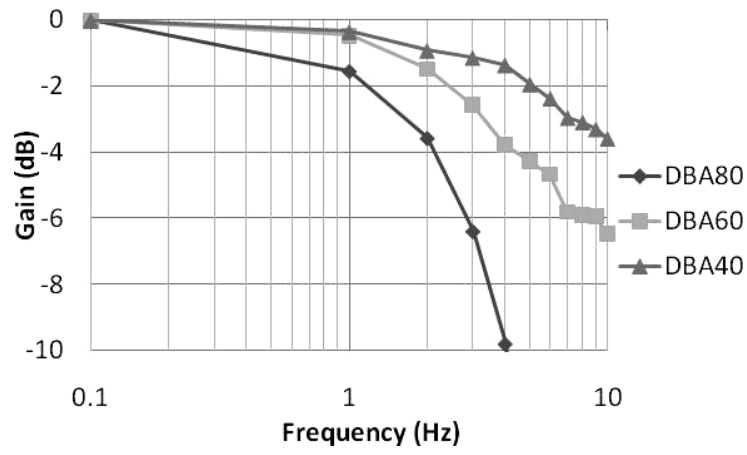

Fig. 17 Gain diagram in displacement

合 $1,800[\mathrm{~V} / \mathrm{mm}]$ の電場を与えたとき, 発生応力は約 $2.9[\mathrm{kPa}]$ であった。また，単層構造と同じく，DBAの量が減少するに 従って発生応力が増大することが分かった。

\section{3 応答性}

DBA80，DBA60，DBA40 を用いたアクチュエータの，変 位のゲイン線図を Fig. 17 に示す，印加電圧は $500[\mathrm{~V}]$ である. DBA40 の場合 $-3[\mathrm{~dB}]$ でのバンド幅が $7[\mathrm{~Hz}]$ で, PVCに対す る可塑剤の含有が少ないものほど応答性がよいことが分かった。

\section{4 繰り返し特性}

DBA60 のアクチュエータに関して, $0[\mathrm{~V}] \sim 500[\mathrm{~V}]$ のパルス (2[Hz]) を 2,000 [s] 間与え, 継続的に動作させたときの変位量 の結果を Fig. 18 に示す。試験における最初の $5[\mathrm{~s}]$ 間の変位と 最後の $5[\mathrm{~s}]$ 間の変位の様子を示した。 4,000 サイクルの繰り返 しに対して，変位の減衰がないことが分かった。

\section{5 印加電場とアクチュエータ剛性}

印加電場とアクチュエータ剛性の関係を調べた。 各印加電場 において微小な強制変位を加え, そのときの反力を計測し, ア

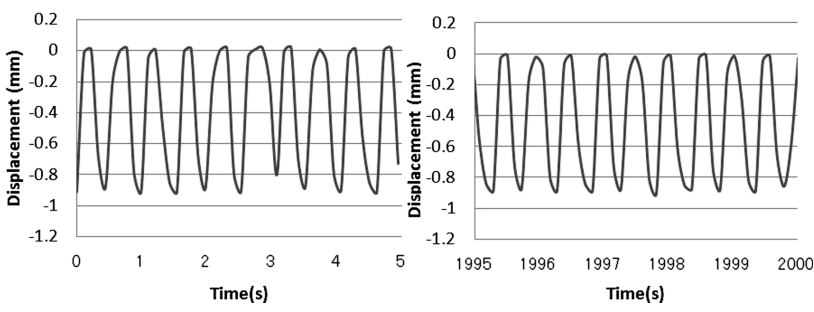

Fig. 18 Characteristic of displacement in repetition (DBA60)



Fig. 19 Actuator stiffness and dc field (DBA40)

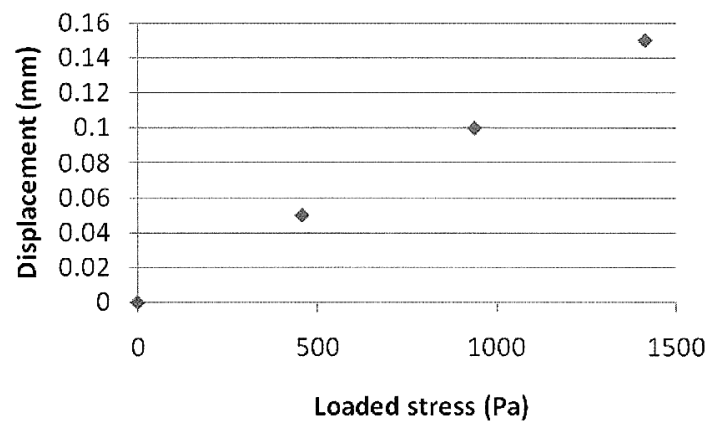

Fig. 20 Relationship between displacement and loaded stress

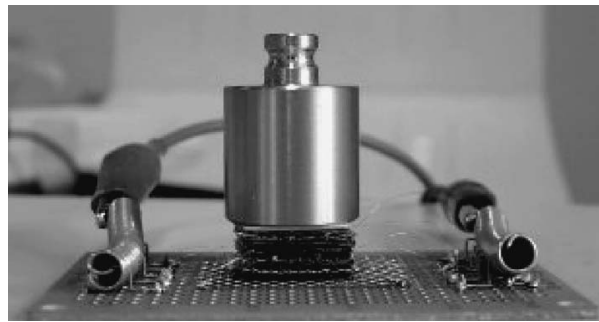

Fig. 21 PVC gel actuator with a load

クチュエータ剛性を求めた。 Fig. 19 にDBA40 の結果を示し た。生体筋では筋活動量に伴い粘弾性が増すことが知られてお り [7], これと同様に印加電場を増すことにより剛性が増大して いることが分かる. Fig. 20 に $800[\mathrm{~V} / \mathrm{mm}]$ の電場を与えたと きの負荷応力と変位の関係を示した. 負荷応力と変位はほぼ比 例している。

\section{6 負荷時の応答性}

積層型 PVC ゲルアクチュエータ（DBA60）に約 $4.5[\mathrm{kPa}]$ の 負荷を与えて駆動実験を行った（Fig. 21）。1,000 [V/mm]の 印加電場の結果を Fig. 22 に示した. 約 $4.5[\mathrm{kPa}]$ の負荷を加 えた場合でも約 $0.5[\mathrm{~mm}]$ の変位が確認できた 
Table 1 Comparison of contraction and expansion type actuator

\begin{tabular}{|c|c|c|c|c|c|}
\hline & Contraction & Expansion & Force & Response & DC field \\
\hline Piezoelectric Element & & -- & ++ & ++ & $1 \mathrm{~V} / \mu \mathrm{m}$ \\
\hline Shape Memory Alloy & - & & ++ & -- & $0.1 \mathrm{~V} / \mathrm{mm}$ \\
\hline Conducting Polymer & + & & + & - & $1 \mathrm{~V} / \mathrm{mm}$ \\
\hline Dielectric Elastomer & & - & + & ++ & $100 \mathrm{~V} / \mu \mathrm{m}$ \\
\hline PVC Gel & + & & - & + & $1 \mathrm{~V} / \mu \mathrm{m}$ \\
\hline
\end{tabular}

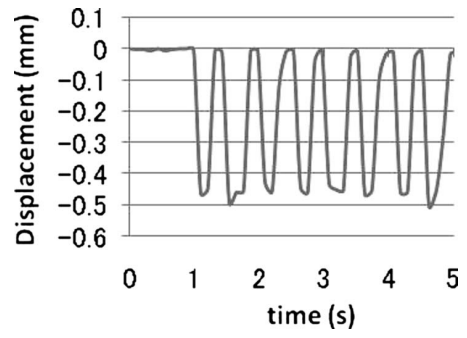

Fig. 22 Displacement of PVC gel actuator (DBA60) with a load

\section{6. 考察}

提案した収縮型 PVC ゲルアクチュエータの特性はおおむね収 縮率 $13 \%$, 発生応力 $3[\mathrm{kPa}]$, 応答性 $7[\mathrm{~Hz}]$ となることが分かっ た，応答性については生体筋のものとほぼ同じレベルに達して いるものと考えられる. 収縮率は生体筋に比べて半分程度であ るが, 電場印加に伴い, メッシュ電極が PVCゲルの侵入で隙間 なく埋めつくされていることを考慮すると, 電極の形状を適切に 設計することにより，収縮率を生体筋により近付けることが可能 であると考えられる. 発生応力については生体筋の $1 / 100$ 程度 になっており，これを増大させることが，本アクチュエータの特 性改善にとって最も重要である。この方策としては, PVCゲル の組成により発生応力が変化することから, 可塑剤である DBA の量を減少させ，PVCゲルの弾性率を上げることが考えられ る. また, 印加電場をさらに大きくすることも発生応力増大につ ながるものと考えられる。これらの課題を達成することにより， 生体筋と同程度の特性を有する人工筋肉の創製が期待できる。

機能材料を用いた従来の収縮型アクチュエータと本アクチュ エータの特性を比較し, Table 1 に示した. 圧電素子 [8] は応答 性と発生応力という点では優れた特性を有する反面, 収縮率が 小さく，変位の増大が困難である．一方，形状記憶合金 [9] [10] は発生応力が生体筋の 10 倍程度と高いが, 温度変化により動作 するため応答性の改善が難しく，また収縮率も $2 \%$ 程度で大きな 変位量を得にくい. 導電性高分子を用いたアクチュエータ [2] は, 低電場駆動という特徵を有し, 収縮率, 発生応力は生体筋と同 程度の特性を有するが応答性が劣る。誘電エラストマを用いた 収縮型アクチュエータ $[2]$ は, 応答性と発生応力に優れるが, 電 場印加時に伸張し，収縮する生体筋とは反対の動きとなる。ま た変位量が小さく印加電場も極めて高いという問題がある. 以 上のように, どのアクチュエータも一長一短があり, 生体筋の 特性に匹敵するものは存在しない。こうしたなかで, 本研究で 提案した収縮型 PVC ゲルアクチュエータは, 発生応力が生体 筋に比べ劣るものの, 収縮率, 応答性ではほぼ同程度の特性を
有しており，上述したように今後多くの特性改善が見达まれる ことから，人工筋肉として有望なアクチュエータである。アク チュエータを拮抗型に配置して関節を駆動させたり，顔ロボッ トの皮膚の下に配置して表情表出に用いることが考えられる。

\section{7.おわりに}

メッシュ電極を正極とした収縮型 PVC ゲルアクチュエータの 構成法を提案し，その駆動特性を単層構造と多層構造を用いた 駆動実験により明らかにした。その結果, 収縮率 $13 \%$, 発生応 力 $3[\mathrm{kPa}]$, 応答性 $7[\mathrm{~Hz}]$ の特性が得られた. 印加電場を大きく することにより生体筋のようにその剛性が増加することも分かっ た。また，可塑剤である DBAの含有量が減少するほど弾性率 は増加し, 収縮率が減少する反面, 発生応力が増大し, 応答性が 向上した. 印加電場は大きいものの, 電流は数十 $[\mu \mathrm{A}]$ のオーダ で効率のよいアクチュエータである。以上により, 大収縮率を有 し，応答性のよい収縮型アクチュエータを実現できたと考える。

今後, 電極形状の改善, ゲル組成の探索を行うことにより, 生 体筋の特性に近い人工筋肉の創製が期待される.

謝 辞 本研究は, 長野上田地域知的クラスター創成事業 (第 II 期）において（株）ハーモニック・ドライブ・システムズ社 の協力を得て実施したものです。ここに深く感謝致します.

\section{参 考 文 献}

[1 1 金藤敬一：“高分子アクチュエータ”, 高分子, vol.55, no.12, pp.956960, 2006.

[2] 長田義仁 編：ソフトアクチュエー夕開発の最前線一人工筋肉の実現 をめざして一. エヌ・ティー・エス, 2004.

[ 3 ] Md. Z. Uddin, M. Watanabe, H. Shirai and T. Hirai: "Creeping and Novel Huge Bending of Plasticized PVC,Journal of Robotics and Mechatronics," vol.14, no.2, pp.161-166, 2002.

[4] 藤井勝哉, 荻原孝文, 平井利博, 木下健：“PVC ゲルのクリープ変形 に及ぼす可塑剤の影響”, Polymer Preprints, Japan, vol.55, no.2, pp.4557-4558, 2006.

[5] 荻原孝文, 藤井勝哉, 平井利博, 木下健：“DBP 含有 PVC ゲルのク リープ変形を利用した人工瞳”, Polymer Preprints, Japan, vol.55, no. 2 , pp.4559-4560, 2006.

[6] 山野美咲, 橋本稔, 平井利博, 高崎緑: "PVC ゲルアクチュエータ の変形特性”, 第 8 回 (社) 計測自動制御学会システムインテグレー ション部門講演会論文集, pp.219-220, 2007.

[7] 梶山他：“収縮反射に着目したヒトの上肢位置制御機構の解析”, バ イオメカニズム 4, pp.59-68, 1978.

[ 8 ] 古屋泰文, 今泉伸夫, 樋口俊郎 監修: 未来型アクチュエータ材料・デ バイス. シーエムシー出版, 2006.

[ 9] 舟久保熙康 編：形状記憶合金. 産業図書, 1984 .

[10] M. Hashimoto, M. Takeda, H. Sagawa, I. Chiba and K. Sato: "Application of Shape Memory Alloy to Robotic Actuators," J. of Robotic Systems, vol.2, no.1, pp.3-25, 1985. 


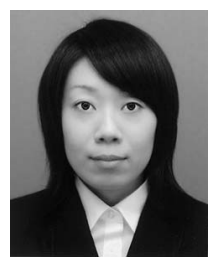

山野美咲（Misaki Yamano）

2008 年信州大学繊維学部感性工学科卒業. 同年同 大学大学院工学系研究科入学, 現在に至る.

（日本ロボット学会学生会員）

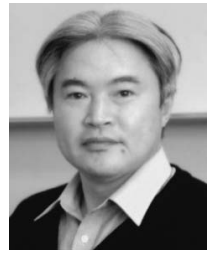

橋本 稔 (Minoru Hashimoto)

1982 年東京大学大学院工学系研究科博士課程退学. 同年電気通信大学短期大学部助手, 1987 年電気通 信大学電気通信学部助手, 1988 年鹿児島大学工学 部助教授, 1999 年信州大学繊維学部教授. 1985 年 米国ペンシルベニア大学客員研究員. 工学博士. 高 分子アクチュエータ, HRI, モーションアシストな どの研究に従事. 日本機械学会, 計測自動制御学会, 日本感性工学会, IEEE などの会員.

（日本ロボット学会正会員）

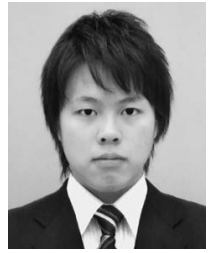

小川尚希（Naoki Ogawa）

2008 年信州大学纎維学部機能機械学科卒業. 同年 同大学大学院工学系研究科入学, 現在に至る. 日本 機械学会学生会員.

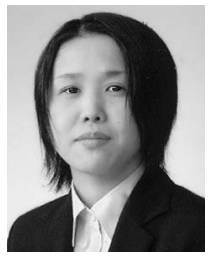

高崎 緑 (Midori Takasaki)

1997 年信州大学繊維学部絨維システム工学科卒業. 2002 年東京工業大学大学院理工学研究科有機材料 工学専攻博士後期課程修了後, カネボウ合繊株式会 社入社, 2004 年信州大学 SVBL 博士研究員, 2007 年信州大学 SVBL 助教, 現在に至る. 高機能材料 に関する研究等に従事. 繊維学会, 高分子学会, プ ラスチック成形加工学会などの会員.



平井利博 (Toshihiro Hirai)

1970 年信州大学繊維学部繊維工業化学科卒業. 1976 年大阪府立大学大学院工学研究科博士課程応用化学 専攻修了. 1976 年米国 Tulane 大学医学部生化学 教室講師を経て, 1979 年信州大学纎維学部助手, 1996 年信州大学繊維学部教授. 高分子ゲルなどの 駆動材料への応用に関する研究に従事. 米国化学 会, 日本化学会, 高分子学会, 繊維学会, 日本機械学会などの正会員. 